\title{
Innovative Digital Guerrilla Marketing
}

\author{
Gerd Nufer
}

\begin{abstract}
Guerrilla marketing is the selection of atypical and non-dogmatic marketing activities that aim to achieve the greatest possible impact - in the ideal case with a comparable minimum investment. Guerrilla marketing has developed into a basic strategy overarching the marketing mix, a basic marketing policy attitude for market development that goes off the beaten track to consciously seek new, unconventional, previously disregarded, possibly even frown-upon possibilities for the deployment of tools. Digital marketing tools such as social media provide new ways and promising opportunities for innovative guerrilla marketing. This article provides an overview of innovative digital guerrilla marketing. It describes and structures guerrilla marketing in a novel form and shows illustrating examples as well as developmental trends.
\end{abstract}

Index Terms - Guerrilla marketing, digital marketing, social media marketing, innovative marketing.

\section{INTRODUCTION}

The willingness of people to be exposed to static, repetitive and thus supposedly boring information and communication is increasingly declining. Classic, conventional forms of advertising are failing more and more clearly, prompting the demand for new, innovative marketing strategies.

In order to keep scattering losses as low as possible, there is an inter-instrumental shift in favor of non-classical marketing communication instruments. Guerilla marketing offers new, unusual possibilities to counter the increasing advertising aversion of the recipients and to win the attention of the target group.

The use of guerrilla marketing is particularly suitable online or digitally - in a sense as the marketing weapon of the "little David" in the fight against established competitors, the "giant Goliath".

\section{Characterization OF Guerrilla Marketing}

The term "guerrilla" comes from the military. "Guerilla" is the diminutive of the Spanish word "guerra", which translated means "war". Thus, "guerilla" means as much as "small war" or "partisan war", which aims at a selective weakening of the opponent [1].

If one transfers the guerrilla concept into marketing terminology, various interpretations and views on the use and functions of guerrilla marketing emerge. Unconventionality is the basic determinant for the characterization of guerrilla

Manuscript received January 5, 2021; revised June 10, 2021. This work was supported by Reutlingen Research Institute (RRI).

Gerd Nufer is with Reutlingen University, ESB Business School, Alteburgstr. 150, 72762 Reutlingen, Germany (e-mail: gerd.nufer@reutlingen-university.de). marketing. Levinson describes guerrilla marketing as follows: "Guerrilla marketing is a body of unconventional ways of pursuing conventional goals. It is a proven method of achieving profits with minimum money" [2].

One of the most comprehensive definitions of guerrilla marketing to date comes from Zerr, who describes guerrilla marketing as an alternative, holistic marketing approach: "The term guerrilla marketing refers to the selection of atypical and undogmatic marketing activities that are intended to achieve the greatest possible impact with the least amount of resources. Guerilla marketing has developed into a basic strategy that transcends the marketing mix, a basic marketing policy approach to market development that deliberately looks outside the well-trodden paths for new, unconventional, previously disregarded, perhaps even frowned-upon possibilities for instrumental use" [3].

There is a multiplicity of further definition beginnings and circumscription attempts, in order to mark Guerilla marketing. However, recurring constitutive characteristics of guerrilla marketing can be identified [4]-[7]. Accordingly, guerrilla marketing is:

- unconventional,

- surprising,

- original/ creative,

- cheeky/ provocative,

- effective,

- flexible,

- unusual/atypical,

- witty,

- spectacular,

- contagious.

In summary, the philosophy of guerrilla marketing is to achieve conventional marketing goals with unconventional methods. In essence, guerrilla marketing aims to be different and to stand out [8]. As a rule, the aim is to achieve the greatest possible impact with a comparatively smaller budget (than is usual in traditional marketing), which is why the use of guerrilla marketing online is particularly suitable in the digital age.

\section{Marketing MiX OF GuerRILla Marketing}

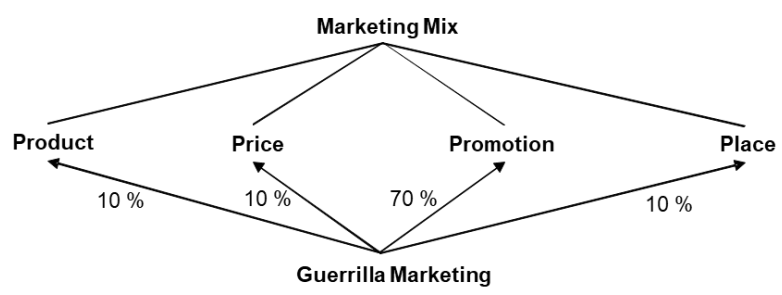

Fig. 1. Application of Guerrilla marketing in the marketing mix [1]. 
With creative and unconventional approaches, guerrilla marketing enriches the entire marketing mix, but typically in varying degrees of application frequency (see Fig. 1).

The concept of guerrilla marketing was initially practiced before it also found its way into the scientific literature with a time lag [7], [9], [10].

\section{COMmunicAtion InStRuments of Digital GuERILla MARKETING}

Guerilla principles can be integrated most effectively into communication policy measures. From this perspective, guerrilla marketing belongs to the non-classical forms of communication policy ("below the line" measures). The use of classic instruments of the communication mix forms the basis on which guerrilla marketing is used selectively as an additive, surprising component of integrated communication [4], [6].

Guerilla marketing can be implemented through different instruments. A unified categorization of the instruments has not yet been able to establish itself. In the following, the most important instruments of guerrilla marketing are divided into different categories (see Fig. 2).

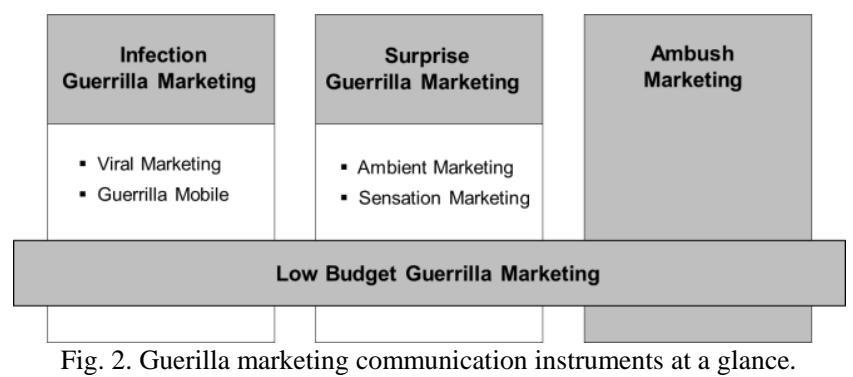

Low Budget Guerilla Marketing is particularly suitable for small and medium-sized companies that have only a very limited marketing budget. While Infection Guerilla Marketing tries to use the possibilities offered by new media in particular, Surprise Guerilla Marketing focuses on communication tools used in public spaces or at special locations. Finally, Ambush Marketing appears in particular in the environment of sporting events [4].

The following characterization of the communication instruments of guerrilla marketing is based on current best practice examples from digital marketing.

\section{A. Low Budget Guerilla Marketing}

Wingstop
@wingstop
Be there. Done that.
Bring something fresh... not frozen. @
twitter.com/wendys/status/...
Wendy's $\diamond @$ Wendys
Replying to @wingstop @Fatlaz901
Sit down, be humble. @
O27.8K 6:11 PM - Oct 2, 2017
11.7K people are talking about this

Fig. 3. Example of digital low budget Guerrilla marketing [11].
For small and medium-sized companies, the focus of communication policy is on directly addressing the (regional) target group through creative, unusual and clever ideas. They aim to emphasize special features and differences and thus give the company a special status in the consumers' eyes.

This approach thrives above all on long-term, consistent commitment [6], [12].

The Internet, especially social media, makes it easy to attract attention with low-cost measures. One example of digital low budget guerrilla marketing is a rap battle on Twitter between the American fast-food chains Wendy's and Wingstop. The duel on the online platform was preceded by a tweet from Wingstop, which resembled the lyrics of a rap. The competitor Wendy's then replied very glibly to the tweet in the same tone. The rap battle generated free attention for both chains and showed that they have mastered the use of social media and the young target group (see Fig. 3).

\section{B. Infection Guerilla Marketing}

Infection guerrilla marketing includes viral marketing and guerrilla mobile marketing.

\section{1) Viral marketing}

The infection strategy of viral marketing is similar to that of biological viruses: Instead of the multiplication of pathogens, however, the focus is on the exponential spread of a marketing message. The consumer himself becomes an advertiser by recommending an offer to his friends or acquaintances - whereby neither the sender nor the recipient of the message perceive the recommendation as advertising. The message can be spread offline from mouth to mouth (word of mouth communication, buzz marketing) or online, virtually from mouse to mouse [8], [13].

The non-profit organization ALSA succeeded in placing an advertisement on the Internet in such a way that it became a self-runner in the summer of 2014 with its Ice Bucket Challenge (see Fig. 4). The challenge consisted of an online video in which people poured a bucket of ice-cold water over their heads and posted the recording online. They were allowed to nominate three other people who had to do the same. The whole thing was published on the relevant social media channels so that it reached all friends and followers. The campaign was intended to draw attention to the nerve disease amyotrophic lateral sclerosis (ALS). At the same time, each participant was asked to donate a certain amount to ALSA to fight the disease. Within one summer, USD 115 million was raised for research and to fight the nerve disease [4].

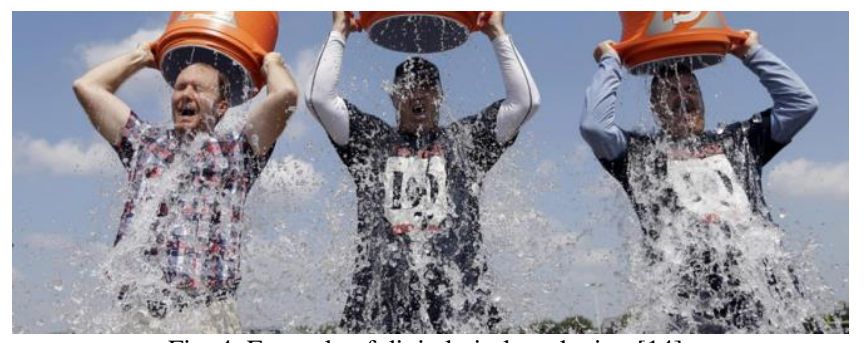

Fig. 4. Example of digital viral marketing [14]

\section{2) Guerilla mobile marketing}

Mobile marketing is concerned with the transmission of 
messages via cell phones. The starting point for the use of guerrilla marketing is that the smartphone has now become a constant companion for many people in all situations of life and the consumer is therefore accessible at all times. Creative and funny messages are used to ensure that the advertising content is not only immediately taken up by the recipient, but ideally also immediately forwarded to friends and acquaintances. The close connection to viral marketing is obvious here [6], [12].

In the age of social networks, the popularity of sweepstakes has risen sharply. Companies announce the raffle of their products on their social channels. The young Danish company Solo Socks, for example, raffled off seven pairs of its socks on Instagram (see Fig. 5). Anyone who followed the company on Instagram and had at least three friends tagged could take part in the draw. If these friends also followed Solo Socks, they had double the chance of winning. By tagging the friends, the promotion was automatically displayed and spread on their smartphones.

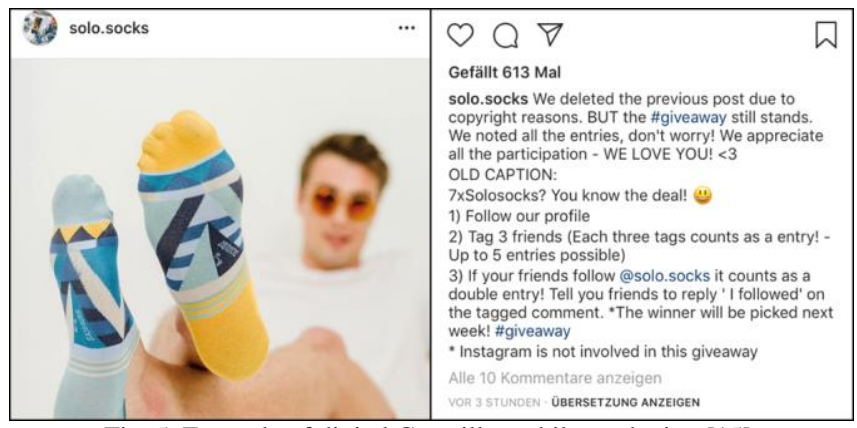

Fig. 5. Example of digital Guerrilla mobile marketing [15]

\section{Surprise Guerilla Marketing}

Surprise guerilla marketing comprises the instruments ambient marketing and sensation marketing.

\section{1) Ambient marketing}

Ambient media is a collective term that includes all non-classical advertising media. Ambient media are placed and integrated in the direct living environment of the recipients - and are therefore not perceived as disturbing, but are often even seen as likeable and original (e.g. postcards in trendy pubs, shower gel samples in changing rooms of fitness studios). Special characteristics of ambient marketing are the radicality, speed and creativity with which public space is appropriated. The consumer is surprised with advertising where he does not expect it. It is not possible to zap away or switch off. Ambient marketing can be planned and also repeated [8], [1].

To promote the movie Deadpool, a fictitious profile of the main character was created on the online dating platform Tinder. While searching for potential partners, users of the app were shown Deadpool's profile as a possible partner. The profile was very much based on the character of the film in terms of its presentation and tone, and at the same time resembled the common appearance of normal profiles. Now it was the user's turn, as the app stipulates that an action must be taken (e.g. swipe to the right). The responsible parties used Tinder's mechanism here to generate induced forced involvement, i.e., to create a high-involvement situation that is used to disseminate advertising messages (see Fig. 6).

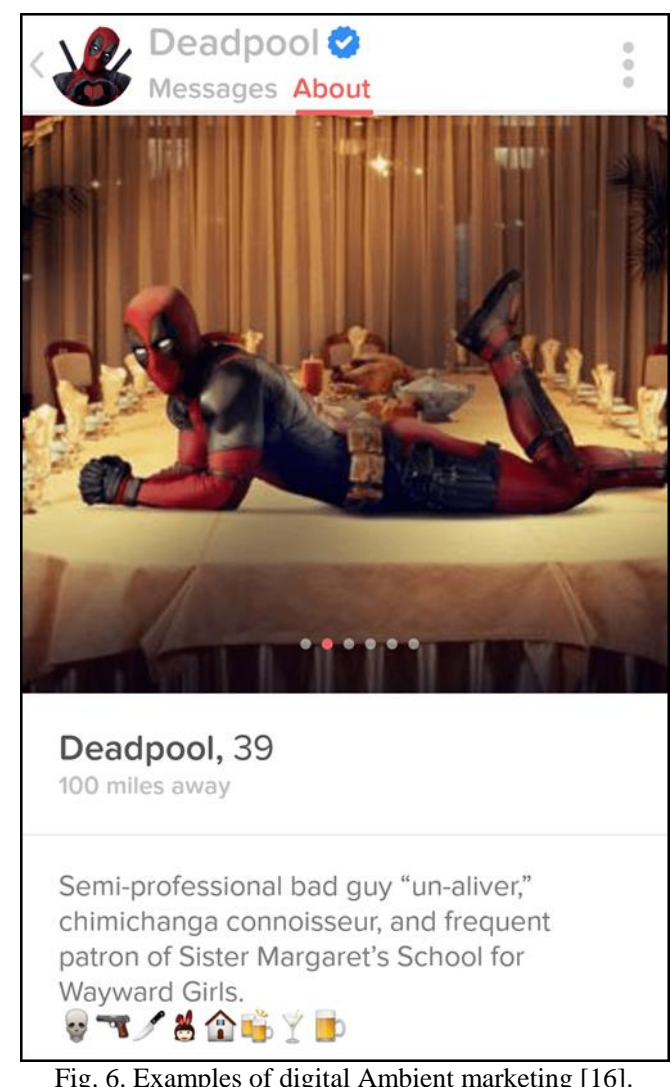

Fig. 6. Examples of digital Ambient marketing [16].

\section{2) Sensation marketing}

Basically, sensation marketing is very similar to ambient marketing. The main difference is that sensation marketing campaigns are usually unique and cannot be repeated. The aim is to surprise and fascinate the recipient and to trigger an "aha" or "wow" effect. The terms guerilla sensation and ambient stunt stand for unusual, spectacular actions [6], [12].

A guerilla sensation refers to a dynamic action in which people are involved. Examples of this are live broadcasts on social media such as Instagram or Facebook. In these broadcasts, followers of a profile are notified without prior notice that a company or public page is going live at that moment. In various formats, for example, a representative of a brand is available to answer users' questions in real time. Only users who tune in during exactly this limited time period have the opportunity to participate in the action.

An ambient stunt is about a spectacular static installation, but presented no less unconventionally. The media-effective actions are carried out at strategically interesting, highly frequented locations in order to attract a high degree of attention. In this form of guerrilla marketing, multipliers are also used in order to inform as broad a public as possible about the action via media dissemination and viral effects. In the fall of 2018, the real estate company Homie from the U.S. state of Utah used the upcoming elections in Arizona to promote its expansion into the capital of the neighboring state, Phoenix. Various online and offline advertisements encouraged voters to vote for Homie and referred them to the homie-forsenate.com website (see Fig. 7). It was only when interested voters visited the website that it was explained that the promised "noticeable change" would be related to the customer's wallet, not the upcoming Senate election. In addition to the direct attention generated by the campaign, the 
company received millions of website visits as a result of numerous news stories.

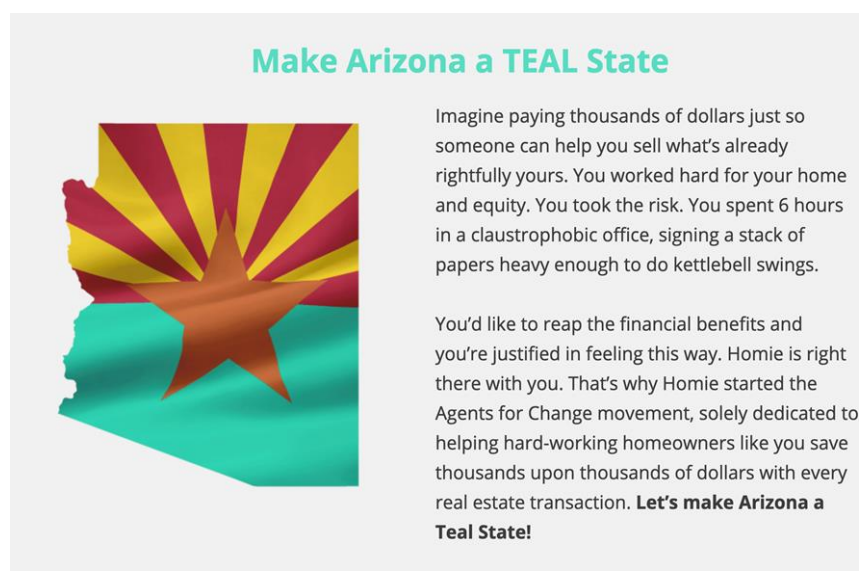

Fig. 7. Example of digital sensation Marketing [17].

\section{Ambush Marketing}

Ambush marketing cannot be subsumed under any of the categories of guerrilla marketing presented so far and is therefore a special case. Ambush marketing is a guerrilla alternative to classic sponsoring. Ambush marketing is the approach of companies to signalize the impression of a connection to the event to the direct and indirect audience of a (sports) event through their own marketing, in particular communication measures, although the companies concerned do not have any legalized or only underprivileged marketing rights to this event sponsored by third parties. In this way, ambushers, analogous to official sponsors, want to promote and sell products via an association with the event in the perception of the recipients [18].

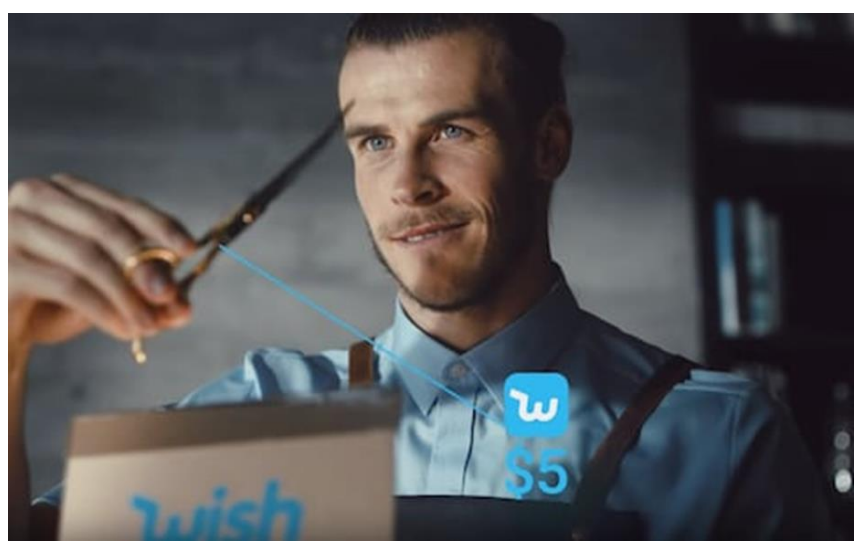

Fig. 8. Example of digital Ambush marketing [19].

What do you do if you are a player and your country has missed out on qualifying for the World Cup? You do the same as Gareth Bale and learn the hairdressing trade (see Fig. 8). In its first global advertising campaign, the online retailer Wish is offering this and many other alternatives to the Welsh superstar and many other soccer players who did not make it to the 2018 World Cup in Russia. Italy's Gianluigi Buffon and U.S. goalkeeper Ben Howard, for example, learned the art of baking with utensils from Wish, the Netherlands' Robin Van Persie devoted himself to gardening and Chile's Claudio Bravo had fun with his new drone. Under the campaign "time is in your hands," Wish used it to specifically promote its very affordable products, which can be purchased online by anyone. Without being an official sponsor of the FIFA World Cup and without the players participating in the tournament, every TV viewer nevertheless understood the reference to the World Cup, since the well-known soccer players are otherwise an integral part of world soccer [4].

\section{CONCLUSION}

Guerilla marketing is a concept that is strongly driven by practice. The lack of scientific knowledge about guerilla marketing, its instruments and its classification can be interpreted in two ways: Guerrilla marketing is not classifiable or guerrilla marketing is difficult to classify.

Digital guerrilla marketing does not make traditional marketing obsolete (in the sense of a revolution), but has a selective supporting effect and helps the marketing mix, mainly communication policy, to a new, innovative coat of paint (in the sense of an evolution). A clear delimitation and unambiguous categorization of the different instruments of digital guerrilla marketing is hardly possible. Rather, the individual instruments complement each other and thus help guerrilla marketing synergistically to its actual effect. The changes in markets, communication and recipients create new opportunities for marketing. Jung/von Matt put it in a nutshell: "It's good to know the most important rules of communication, because then you can break them in a more targeted way" [20].

\section{CONFLICT OF INTEREST}

The author declares no conflict of interest.

\section{ACKNOWLEDGMENT}

The article processing charge was funded by the Baden-Württemberg Ministry of Science, Research and Culture in the funding programme Open Access Publishing.

The author gratefully acknowledges the research assistance provided by David Mariot for this research project.

\section{REFERENCES}

[1] T. Schulte, Guerilla Marketing für Unternehmertypen, 3rd ed Sternenfels: Wissenschaft \& Praxis, 2007.

[2] J. C. Levinson. (June 2018). Guerilla Marketing. [Online]. Available: http://www.gmarketing.com

[3] K. Zerr. (June 2018). Guerilla Marketing in der Kommunikation: Kennzeichen, Mechanismen und Gefahren. [Online]. Available: http://www.guerilla-marketing-portal.de/doks/pdf/Guerilla-Zerr.pdf

[4] G. Nufer, "Guerilla marketing — Unorthodoxes marketing von David im Kampf gegen Goliath," PraxisWissen Marketing — German Journal of Marketing, no. 1, pp. 69-85, 2019.

[5] T. Patalas, Guerilla Marketing - Ideen schlagen Budget, Berlin Cornelsen Scriptor, 2006.

[6] M. Jäckel, "Guerilla-Marketing — Grundlagen, Instrumente und Beispiele," Erfurter Hefte zum angewandten Marketing, no. 15, pp. 3-12, 2007.

[7] J. C. Levinson, Guerilla Marketing des 21. Jahrhunderts. Clever werben mit jedem Budget, 3rd ed. Frankfurt/Main: Campus, 2018.

[8] A. Förster and P. Kreuz, Marketing-Trends. Innovative Konzepte für Ihren Markterfolg, 2nd ed. Wiesbaden: Gabler, 2006.

[9] G. Nufer, "Guerrilla marketing — Innovative or parasitic marketing?" Modern Economy, vol. 4, no. 9, pp. 1-6, 2013.

[10] G. Nufer, "Guerrilla marketing — Structuring the manifestations and critical evaluation," Innovative Marketing, vol. 9, no. 2, pp. 60-68, 2013. 
[11] Twitter. (October 2017). Wendy's. [Online]. Available: https://twitter.com/wendys/status/914959134327484416

[12] T. Schulte and M. Pradel, Guerilla Marketing für Unternehmertypen, 2nd ed. Sternenfels: Wissenschaft \& Praxis, 2006.

[13] S. Langner, Wie Sie Mundpropaganda gezielt auslösen und Gewinn bringend nutzen, Wiesbaden: Springer Gabler, 2005.

[14] The Atlantic. (August 2014). The California Drought Versus the Ice Bucket Challenge. [Online]. Available: https://www.theatlantic.com/national/archive/2014/08/the-california-d rought-versus-the-ice-bucket-challenge/ 378776

[15] Instagram. (June 2018). Solo Socks. [Online]. Available: https://www.instagram.com/solo.socks

[16] Imgur. (February 2016). Deadpool's Tinder Profile. [Online] Available: https://imgur.com/gallery/Q1GxHKu

[17] Homie. (June 2018). Homie for Senate. [Online]. Available: http://homieforsenate.com

[18] G. Nufer, Ambush Marketing im Sport. Grundlagen — Best Practice - Evaluation, 2nd ed. Berlin: Erich Schmidt Verlag, 2018.

[19] Telegraph. (June 2018). The rise of Wish.com - The \$8.5bn Amazon rival flogging knockoffs and knick-knacks. [Online]. Available: https://www.telegraph.co.uk/technology/2018/07/16/wishcom-85bn-a mazon-rival-flogging-knockoffs-knick-knacks
[20] H. Jung and J.-R. Matt, Momentum. Die Kraft, 2nd ed. Berlin: Lardon, 2002.

Copyright $\odot 2021$ by the authors. This is an open access article distributed under the Creative Commons Attribution License which permits unrestricted use, distribution, and reproduction in any medium, provided the original work is properly cited ( $\underline{\text { C BY } 4.0)}$.

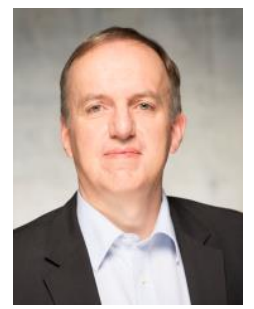

Gerd Nufer is professor of business administration specializing in marketing, retail and sports management at ESB Business School, Reutlingen University, Germany.

Gerd Nufer heads the Institute for Marketing, Communication \& Market Research and the German Institute for Sports Marketing. He has many years of practical experience in business.

Prof. Nufer's teaching, research and consulting specializations are marketing communications, event management, sports marketing and international marketing research. $\mathrm{He}$ is the author of numerous scientific articles in national and international publications. He has received several awards for his research and teaching. 